\title{
Financial frictions and the cash flow - external financing sensitivity: evidence from a panel of Pakistani firms
}

\author{
Abdul Rashid ${ }^{*}$ and Noshaba Jabeen
}

\author{
* Correspondence: Ch.arahmad@ \\ yahoo.com \\ International Institute of Islamic \\ Economics (IIIE), International \\ Islamic University (IIU), $\mathrm{H}-10$, \\ Islamabad 44000, Pakistan
}

\begin{abstract}
This paper uses a large panel of Pakistani non-financial firms over the period 20002013 to examine the role of financial constraints in establishing the relationship between cash flow and external financing. The results reveal that there exists a negative and significant relationship between external financing and cash flow. The finding of the substitutionary relation between internal funds availability and external financing has been viewed as evidence supporting the pecking order theory of capital structure. Yet, we show that this negative relationship is weak in case of financially constrained firms. We also analyze how credit multiplier affects external financing decisions of financially constrained and unconstrained firms. The results show that for financially unconstrained firms, the negative sensitively of external financing increases with asset tangibility. However, for financially constrained firms, the negative sensitivity of external financing to cash flow either decreases or turns positive as the tangibility of assets increases. This finding implies that financially constrained firms benefit more from investing in tangible assets because such assets not only help relax financial constraints but also having a potential to be a direct source of funds in periods of negative cash flow shocks.
\end{abstract}

Keywords: External financing, Cash flows, Internally generated funds, Financial constraints, Investment, Credit multiplier

JEL classification: G31

\section{Introduction}

Financial frictions mean financial constraints that prevent corporate firms from funding all desirable investments from external resources. ${ }^{1}$ This financing incapability might be due to either the inability or the reluctance of firms to issue new equity and debt instruments, the inability of firms to borrow from financial intermediaries, the greater dependence of firms on bank loans, the prevalence of credit constraints, or the illiquidity of firms' assets. One of the primary objectives of a firm's financial policy is to maintain its financial flexibility. An effective financial policy does not only ensure funds for the present but also for the future investments. The value of financial flexibility further increases when financial markets suffer from frictions and financing restrictions compel firms to pass up some profitable investment opportunities due to unavailability of capital (Graham \& Harvey (2001)). The previous empirical research on firms' capital structure 
decisions also provided evidence that financially constrained firms are expected to get less funds in periods when financing costs are higher (Faulkender \& Petersen (2006), Hubbard (1998), Fazzari et al. (1988), and Carpenter \& Petersen (2002)).

According to the pecking order theory, asymmetric information costs play an important role in determining the capital structure choice of firms. Therefore, financially unconstrained firms are likely to depend less on internal funds than their financially constrained peers (Myers \& Majluf (1984)). Further, owing to information asymmetries, firms prefer debt to equity financing when go for external funds and issue equity only as a last resort. Since information asymmetry increases the external financing cost and since financially constrained firms suffer more from information asymmetries, their external financing should more strongly negatively relate to cash flows. Thus, for a given level of investment, profitable financially constrained firms require less external capital to finance their investments, and therefore, they are less likely to tap the external capital markets. However, one should note that this argument assumes that a firm determines its level of investment before determining the optimal amount of debt and equity to issue (Myers (1984)).

Several recent studies such as Almeida \& Campello (2010) and Gracia \& Mira (2014) have documented strong evidence on the role of financial frictions in determining the relationship between internally generated funds (cash flows) and the funds obtained from the external capital markets. These studies have explained that information asymmetries have an important role to play in deciding the capital structure of corporate firms. Doing empirical analysis for developed countries, they have provided strong evidence on the negative association between cash flows and external financing. Yet, they show that this negative relationship is relatively stronger for financially constrained firms. The more negative and statistically significant relationship between internal funds and external financing for financially constrained firms implies that financially constrained firms' investing decisions are determined endogenously and strongly depend on internally generated funds. On the other hand, the investment decisions of financially unconstrained firms might be mainly determined exogenously, showing no significant dependence on cash flows.

Although information asymmetry is expected to play a significant role in formulating the linkages between internal funds and external financing, it is not the whole story. As stated by Almeida \& Campello (2010), financially constrained firms are more reliant on internally generated funds while making investment decisions. On the flip side, financially unconstrained firms are generally free to make decisions regarding investment. Said differently, investment is exogenous for unconstrained firms. Thus, Almeida and Campello stated that in case of financially constrained firms, the endogeneity of investment is the fundamental cause for the negative sensitivity of external funds to cash flows. However, it should be noted that the standard pecking order theory of capital structure does not take into account any possibility that firm investment may become endogenous when firms face credit constraints.

There is also an intense debate on the role of credit multiplier in establishing the external financing - cash flows relationship. The credit multiplier is considered as an additional instrument, which makes the relationship between cash flows and external funds less negative. Financially constrained firms suffer more from adverse selection costs than the financially unconstrained firms do. Therefore, creditors require more 
loan guarantees, mainly in terms of pledging tangible assets, in order to save their contracts while lending to financially constrained firms. Thus, financially constrained firms are likely to invest excess of their internal funds in tangible assets such as plant, property, and equipment. Possession of more tangible assets makes easy for financially constrained firms to acquire external funds. Several previous studies including Campello \& Hackbarth (2012), Almeida \& Campello (2007), Bernanke et al. (1996), and Kiyotaki \& Moore (1997) have suggested that the tangibility of assets increases the capability of financially constrained firms to seek new funds. Almeida \& Campello (2007) provided evidence that firms increase their tangible assets when they are in periods of positive income shocks which in turn increase firms' capacity for new credit and as a result more tangible assets and so on. Almeida \& Campello (2010) and Gracia \& Mira (2014) demonstrated that financially constrained firms are more sensitive to increase the holdings of tangible assets. Therefore, the credit multiplier effect is expected to be more prominent in case of financially constrained firms than for unconstrained firms.

Previous empirical research on the link between cash flows and external financing is scant. The most of the previous existing studies such as Almeida \& Campello (2010), Gracia \& Mira (2014), and Schoubben \& Van Hulle (2011) have explored the issue for developed countries only. However, when we review the literature for developing countries, we observe that researchers have not paid considerable attention on the external financing-cash flows relationship. Rather, most of the previous studies in emerging and developing countries have focused on exploring the capital structure determinants. With reference to Pakistan, the literature is also silent on the issue how firms' make external financing decisions when they face financial constrains. Yet, in developing countries, like Pakistan, firms probably face higher financial constrains, as financial markets in these countries are more likely to experience the financial frictions. The prevalence of financial market frictions due to under developed financial system and capital market and unfavorable banking sector policies for corporate firms significantly increase adjustment costs, which, in turn, considerably affect the external financing choices of firms. Furthermore, such market conditions are expected to have a significant impact on the relationship between cash flow and firms' external financing decisions. Therefore, to get a complete understanding of how financial constrains affect the substitution between internal and external funds, it would be worthwhile to get empirical evidence on this issue from emerging and developing countries.

Another gap in the literature is that there is little empirical evidence on the role of credit multiplier in external financing decision for developing countries. However, there are numerous studies in developed countries regarding the role of credit multiplier effect on the external financing-cash flow relationship (Almeida \& Campello (2007), Bernanke et al. (1996), and Kiyotaki \& Moore (1997)). These studies concluded that in case of financially constrained firms, credit multiplier plays an important role in getting new external funds. In developing countries, there are more financial frictions and uncertainty and therefore, creditors require more securities/collateral for their loans. In this context, empirical evidence on the impact of credit multiplier for emerging and developing countries would really help firm managers to understand the role of tangible assets in mitigating the impact of financial constraints.

Pakistan provides a good setting for testing these both issues. In Pakistan, financial markets suffer highly from financial frictions, as economic, financial, and political uncertainty 
is showing a hiking trend due to energy crisis, political unrest, and ongoing long lasting fight against terrorism. Given all these, firms operating in Pakistan not only face higher credit constraints, suffer more from information asymmetries, and pay more costs for external funds but also have to provide more collaterals to seek funds from external capital markets. In this context, the role of financial frictions and the credit multiplier in establishing the linkages between cash flows and external financing would be worth exploring.

This paper using a large panel of Pakistani non-financial firms over the period 2000-2013 examines the role of financial constraints in establishing the relationship between cash flows and external financing. The paper also investigates the credit multiplier effect for financially constrained and unconstrained firms. We use three different measures namely Kaplan and Zingales index (hereafter $\mathrm{KZ}$ index), the debt to asset ratio, and the interest coverage ratio to classify the firm-year observations into financially constrained and unconstrained.

Our results indicate that the external financing decisions of firms are negatively, significantly related to internal funds availability. The finding of the substitutionary relation between internal funds availability and external financing has been viewed as evidence supporting the pecking order theory of capital structure. However, the results reveal that this negative external financing - cash flow sensitivity is less for financially constrained firms. This finding has been inferred as evidence suggesting the interdependence of external financing and investment decisions of financially constrained firms. We also find that for financially unconstrained firms, the negative sensitively of external financing increases with tangibility. On the other end of the continuum, for financially constrained firms, the negative sensitivity of external financing to cash flow either decreases or at least turns positive as the tangibility of assets increases. The greater complementarity between external financing and cash flow for those financially constrained firms that have higher tangible assets implies that these firms benefit more from investing in tangible assets because such assets not only help relax financial constraints but also having a potential to be a direct source of funds, particularly in periods of negative cash flow shocks.

The rest of the paper is structured as follows. Section "Literature Review" presents the literature review. Section "Data and Methodology" describes the data and the empirical methodology applied to carry out the empirical analysis. Section "Empirical Results" presents our main empirical results. Finally, Section "Conclusions" concludes.

\section{Literature review}

\section{Financial frictions, investment endogeneity and the external financing - cash flow} relationship

The previous literature on the capital structure decisions of firms documented significant evidence regarding the role of financial frictions in firms' financing decisions (Fazzari et al. (1988), Hubbard (1998), and Faulkender \& Petersen (2006)). Fazzari et al. (1988) are the pioneer to examine the relationship between investment, internally generated funds (cash flow) and financial constraints. By sorting US firms over the year 1970-1984, they conclude that financial constraints play a significant role in defining the direction and the extent of the relationship between investment and cash flow. However, Faulkender \& Petersen (2006) used a large sample of US firms over the period 1986-2000 and find that small firms are more credit constrained than large firms and the financially unconstrained firms use more leverage in their capital structure as compared to financially constrained firms. 
Several later studies also do not support the findings of Fazzari et al. (1988). For example, Kaplan \& Zingales (1997) found that the relationship between financial frictions and the investment-cash flow sensitivity is nonlinear. They develop new index to classify the firms into financially constrained and unconstrained types, popularly known as KZ index. They explained that most highly financially constrained and unconstrained firms both exhibit higher sensitivity of investment to cash flow than the middle class firms do. Diverging from the large body of the existing literature of the sensitivity of investment to cash flow, they show that the investment decisions of the least financially constrained firms are most sensitive to cash flow. Several other empirical papers including Kadapakkam et al., (1998) and Cleary (1999) supported these findings. In particular, Cleary (1999) examining a large sample of listed firms provided evidence that the investment decisions of high (less) creditworthy firms are more (less) sensitive to internal cash flow availability.

However, Allayannis \& Mozumdar (2004) examined the robustness of the results of Kaplan \& Zingales (1997) and Cleary (1999) by arguing that the investment decisions of firms with cash losses cannot be sensitive to the availability of internal funds (cash flows). They shown that although Cleary's results are strongly robust to such negative cash flow sample, the Kaplan-Zingales results are generally the result of the presence of a few influential observations in a relatively small sample. Further, the authors find a significant decline in the sensitively of investment to internal funds availability. In particular, they show that this decline is more substantial in case of most constrained firms.

Brown \& Petersen (2009) argued and empirically shown that the decline or disappearance of investment-cash flow sensitivity is partly because of a shifting priority (at least among U.S. firms) from investing in fixed capital to investing in R\&D and cash reserves. ${ }^{2}$ Similarly, Chen \& Chen (2012) also recorded a significant decline in the sensitivity of investment to cash during the credit crunch of 2007-2009. If this is indeed the case, then one may argue that examination of the external finance-cash flow relationship might be a better way to study financing frictions in modern firms.

Almeida \& Campello (2007) examined the relationship between investment and cash flow for American manufacturing firms for the period 1985-2000. They show that the tangibility of assets strengthens the relationship between investment and cash flow for capital-constrained firms. They also state that financing restrictions have a significant impact on the investment choices of corporate firms. Another study by Kim (2014) using the data covering the period 1990-2008 provided evidence that compared to capital-unconstrained firms, financially unconstrained firms have higher sensitivity of investment to cash flow.

Several other studies have also examined the relationship between the profitability of firms and the debt to equity ratio. For example, Rajan \& Zingales (1995) using a panel of US listed firms found that the relationship between firm profitability and the debt to equity ratio is negative. Lemmon \& Zender (2010) concluded that some of the patterns observed in the capital structure decisions of firms are highly consistent with the pecking order theory. Shyam-Sunder and Myers (1999) using a sample of 157 US firms documented that most of the firms use debt financing to finance their financing deficits. Fama \& French (2002) and Myers (1977) also supported the pecking order theory and conclude that firms first prefer internal cash flow and then use the external funds. Brav 
(2009) examined the financial behavior of UK private and public firms and find that private firms, which are generally considered financially constrained firms, have less financial flexibility because they experience more information asymmetry as compared to publicly listed firms. Caglayan \& Rashid (2014) using a larger panel of public and nonpublic/private UK manufacturing firms documented that compared to publicly listed firms, the leverage decisions of nonpublic firms are more affected by firm-specific risk. Arslan-Ayaydin, Florackis, \& Ozkan (2014) doing empirical analysis for a large set of East Asian firms over the period 1994-2009 found that firms that are financially flexible prior to the financial crisis of 2007-2008 are more capable to do investment and do not highly rely on the availability of internal funds to invest.

The presence of the negative external financing - cash flow relationship seems inconsistent with the prediction of the trade-off theory of capital structure. According to the trade-off theory, more profitable firms used more external financing (debt) because to harvest the benefits of debt tax shield. If tax benefits are more attractive, then firms prefer debt financing instead of utilizing internal funds. Graham (2000) found that firms could get benefit from the taxes until the cost associated with taxes are less than the bankruptcy cost. Therefore, large and higher profitable firms used debt conservatively. The recent literature suggests that the relationship between internal and external financing is negative because of adjustment costs. For example, Strebulaev (2007) found a negative and significant relationship between firm profitability and leverage for only those firms that are not able to readjust their capital structure.

Almeida \& Campello (2010) working on the panel data of US firms covering the period of more than 30 years examined the role of financial frictions in establishing the relationship between cash flow and external funds. They used four different firm characteristics to identify financially constrained and unconstrained firms. They found a negative and statistically significant external financing - cash flow relationship for financially unconstrained firms. One the other hand, in case of financially constrained firms, they found that external financing is less negatively or statistically insignificantly related to internal funds. They suggested that due to the endogenous nature of investment, there exists a complementarity between the internally generated funds and external financing for financially constrained firms.

Gracia \& Mira (2014) using a large panel of Spanish firms explored the relationship between external funds and internally generated funds for financially constrained and unconstrained firms. They found that for both types of firms, the relationship between external financing and internal funds is negative. Yet, for financially constrained firms, this relationship is less negative. They argued that for unlisted firms, investment is endogenously determined and thus, these firms are strongly depended on the internal funds while making investing decisions. However, they suggested that although the investment of publicly listed companies is exogenously determined, they are likely to reduce leverage by using excess cash flow.

\section{Credit multiplier and the external financing - cash flow relationship}

As we said above, there is very limited empirical evidence on the role of credit multiplier on the relationship between external financing and cash flow for financially constrained and unconstrained firms. The credit multiplier mechanism implies that financially constrained firms face more complementarity between cash flow and 
external funds. According to Almeida \& Campello (2007), financially constrained firms should show more complementarity between the external financing - cash flow relationship because of higher tangible assets. Campello \& Hackbarth (2012) used data covering the period 1971-2005 and study the impact of asset tangibility on firms' investment and financing decisions. They found that compared to financially unconstrained firms, financially constrained firms get more benefits by investing in tangible assets because such assets allow firms to do further investment by relaxing financial constraints.

Gracia \& Mira (2014) found that in order to overcome the problem of external financing constraints, financially constrained firms prefer to hold more tangible assets. Almeida \& Campello (2010) tested the external financing - cash flow relationship through collateral channel and find that the cash flow coefficient is more positive for financially constrained firms as compared to unconstrained firms. Similar results are also presented by Bernanke et al., (1996) and Kiyotaki \& Moore (1997). Their findings also support the macroeconomic literature, showing that more collaterals help relax external financing constraints. Finally, another aspect of tangible assets is their potential to be a direct source of funds. Financially constrained firms, particularly when they confront negative cash flow shocks, can raise funds from sales of tangible asset (see, for example, Borisova \& Brown (2013) and Brown \& Petersen (2015)).

\section{Data and methodology}

Data and sample description

To carry out the empirical analysis, we take a large panel of 450 non-financial firms listed at Pakistan Stock Exchange during the sample period. In particular, we create an annual panel dataset covering the period from 2000 to 2013 using the "Balance Sheet Analysis of Non-Financial Firms" published by State Bank of Pakistan (SBP). As the capital structure of financial firms is different from non-financial firms, we exclude them from the sample. To overcome the problem of selection bias we, allow entry and exit of the firms in our dataset. Therefore, our data is an unbalanced panel data.

\section{Models and variables}

In order to examine the relationship between external financing and cash flow, we follow Almeida \& Campello (2010), Portal et al., (2012), and Gracia \& Mira (2014). We consider two different models that enable us to analyze the external financing and cash flow relationship for both financially constrained and unconstrained firms. What follows below we explain both of these models.

\section{External financing-cash flow sensitivity: the role of financial frictions}

We consider external funds as a function of internally generated cash flow. Our model also includes firm growth and firm size as control variables. The main focus of the study is to examine the effect of cash flow on the external financing decisions of firms in the presence of financial restrictions. We also take into consideration firm size because large firms can easily substitute between external and internal funds to benefit from economies of scale. Our model also includes growth opportunities, as it is well established in corporate finance literature that growth opportunities have a positive and 
significant impact on external financing. Therefore, to examine the net effect of cash flow on external financing, we control for the effects of size and growth opportunities. Specifically, the baseline model takes the following form. ${ }^{3}$

$$
\begin{gathered}
\text { EXTERNAL_FINANCING } \mathrm{i}_{\mathrm{i}, \mathrm{t}}=\alpha_{1} \text { CASH_FLOW }_{\mathrm{i}, \mathrm{t}}+\alpha_{2} \text { GROWTH }_{\mathrm{i}, \mathrm{t}}+\alpha_{3} \text { SIZE }_{\mathrm{i}, \mathrm{t}} \\
+\eta_{\mathrm{i}}+\eta_{\mathrm{t}}+\epsilon_{\mathrm{i}, \mathrm{t}}
\end{gathered}
$$

where EXTERNAL_FINANCING ${ }_{i, t}$ is the dependent variable and it shows changes in external financing for $i$ th firm at the time $t .{ }^{4} \eta_{i}$ and $\eta_{t}$ are firm- and time-specific effects, respectively, and $\epsilon_{\mathrm{i}, \mathrm{t}}$ is the disturbance term and is used to capture the unobserved shocks in the model.

We extend the baseline model presented in Eq. (1) by taking into consideration firms' previous internal financing and their internal liquidity level (extended model henceforth). Following earlier researches including Fazzari \& Petersen (1993), Almeida et al., (2004), Almeida \& Campello (2010), and Rajan \& Zingales (1995), we control already available stock of internal funds and other working capital to avoid the cash flow shocks. Specifically, the extended model takes the following form:

$$
\begin{gathered}
\text { EXTERNAL_FINANCING } \mathrm{i}_{\mathrm{i}, \mathrm{t}}=\alpha_{1} \text { CASH_FLOW }_{\mathrm{i}, \mathrm{t}}+\alpha_{2} \text { GROWTH }_{\mathrm{i}, \mathrm{t}}+\alpha_{3} \text { SIZE }_{\mathrm{i}, \mathrm{t}} \\
+\alpha_{4} \text { CASH }_{\mathrm{i}, \mathrm{t}-1}+\alpha_{5} \text { INVENTORY }_{\mathrm{i}, \mathrm{t}-1}+\alpha_{6} \text { PPE }_{\mathrm{i}, \mathrm{t}-1} \\
+\alpha_{7} \text { DEBT }_{\text {EQUITY }} \mathrm{EN}_{\mathrm{i}, \mathrm{t}-1}+\alpha_{8} \text { EXTERNAL_FINANCING }_{\mathrm{i}, \mathrm{t}-1} \\
+\eta_{\mathrm{i}}+\eta_{\mathrm{t}}+\epsilon_{\mathrm{i}, \mathrm{t}}
\end{gathered}
$$

In Eq. (2), we also include the beginning-of-the-year stock of cash and liquid securities (CASH), accounts receivables and inventory items (INVENTORY), gross plan, property, and equipment (PPE), and the debt to equity ratio (DEBT/EQUITY) into the specification. Further, we include one-period lagged value of the external financing variable as an independent variable to control for dynamic nature of capital structure decisions. As the focus of this study is to check whether the external financing - cash flow relationship differs across financially constrained and unconstrained firms, following the existing capital structure literature, we estimate Eq. (2) separately for financially constrained and unconstrained firms.

\section{Credit multiplier test}

To examine the effect of credit multiplier on the relationship between external financing and cash flow, we run the following model.

$$
\begin{aligned}
& \text { EXTERNAL_FINANCING } \mathrm{i}_{\mathrm{i}, \mathrm{t}}=\alpha_{1} \text { CASH_FLOW } \mathrm{i}_{\mathrm{i}, \mathrm{t}}+\alpha_{2} \text { GROWTH }_{\mathrm{i}, \mathrm{t}}+\alpha_{3} \text { SIZE }_{\mathrm{i}, \mathrm{t}} \\
& +\alpha_{4} \text { TANGIBILITY }_{\mathrm{i}, \mathrm{t}}+\alpha_{5}\left(\mathrm{CASH}_{-} \text {FLOW } \times \text { TANGIBILITY }\right)_{\mathrm{i}, \mathrm{t}} \\
& +\alpha_{4} \mathrm{CASH}_{\mathrm{i}, \mathrm{t}-1}+\alpha_{5} \mathrm{INVENTORY}_{\mathrm{i}, \mathrm{t}-1}+\alpha_{6} \mathrm{PPE}_{\mathrm{i}, \mathrm{t}-1} \\
& +\alpha_{7} \text { DEBT }_{\text {EQUITY }} \text { E,t-1 }+\alpha_{8} \text { EXTERNAL_FINANCING }_{\mathrm{i}, \mathrm{t}-1} \\
& +\eta_{\mathrm{i}}+\eta_{\mathrm{t}}+\epsilon_{\mathrm{i}, \mathrm{t}}
\end{aligned}
$$

Following Gracia \& Mira (2014), we define TANGIBILITY as dummy variable, which takes value 1 if the value of tangibility is above the sample mean and otherwise 0 . 


\section{Financial constraints criteria}

There are different approaches to divide the sample firms into financially constrained and unconstrained type. These approaches generally include asset size, annual payout distribution, commercial paper ratings, bond ratings, costs of external financing, the interest coverage ratio, and Wu and Whited index (Whited \& Wu (2006)). We use the following three criteria for classifying firm-year observations as financially constrained and unconstrained.

Scheme 1: Following Kaplan \& Zingales (1997), we separate financially constrained and unconstrained firms by constructing the following index.

$$
\begin{aligned}
\mathrm{KZ} \text { index }_{\mathrm{i}, \mathrm{t}}=-1.002 \times & \mathrm{CF}_{\mathrm{i}, \mathrm{t}}+0.283 \times \mathrm{Q}_{\mathrm{i}, \mathrm{t}}+3.139 \times \mathrm{LEV}_{\mathrm{i}, \mathrm{t}}-39.368 \times \mathrm{DIV}_{\mathrm{i}, \mathrm{t}} \\
& -1.315 \times \mathrm{CH}_{\mathrm{i}, \mathrm{t}}
\end{aligned}
$$

where

$\mathrm{CF}_{\mathrm{i}, \mathrm{t}}$ represents cash flow.

$\mathrm{Q}_{\mathrm{i}, \mathrm{t}}$ is investment opportunities which is measured as market/book ratio.

$\mathrm{LEV}_{\mathrm{i}, \mathrm{t}}$ represents firms' leverage and it's a total liabilities/total assets.

DIV $_{\mathrm{i}, \mathrm{t}}$ is the dividend payout.

$\mathrm{CH}_{\mathrm{i}, \mathrm{t}}$ represents cash holdings of Firms.

We rank firms into two groups on the basis of $\mathrm{KZ}$ index. Firms with the $\mathrm{KZ}$ index above the sample mean are considered as financially unconstrained and are considered financially constrained otherwise. Although the $\mathrm{KZ}$ index has widely been used in the previous empirical literature for measuring financial constraints, several studies have critiqued the performance of the $\mathrm{KZ}$ index in identifying financially constrained and unconstrained firms (e.g., Almeida et al., (2004) and Hadlock \& Pierce (2010)). ${ }^{5}$ Therefore, we use two other measures of financial constraints as well.

Scheme 2: We also classify the sample firms into two groups based on the interest coverage ratio. The interest coverage ratio is the ratio of earnings before interest and tax to financial expenses. Greater the interest coverage ratio, the fewer the problem the firm would have to face in repaying its debt. Thus, if a firm's interest coverage ratio is above the sample mean, it is considered as financially unconstrained (see, for example, Whited (1992) and Baños-Caballero et al. (2014)). We also considered the mean value of the interest coverage ratio to divide the firm-year observations into financially constrained and unconstrained type. Firms with the interest coverage ratio above the mean are considered as financially unconstrained, whereas, firms having value below the mean of all firms are considered as financially constrained firms

Scheme 3: Finally, we divide the sample firms based on the debt to assets ratio. Arugaslan \& Miller (2006) also used the debt to asset ratio to divide the firms into financially constrained and unconstrained types. The debt to asset ratio is the sum of short-term and long-term debt to book value of assets. We use this measure to classify the firms into financially constrained and unstrained. If the debt to assets ratio of a firm is greater (less) than the mean value of all firms, the firm is considered as financially constrained (unconstrained). We use three different measures to ensure the robustness of our empirical results

The definition of variables used in the study is given in Table 1. Summary statistics are presented in Tables 2 and 3. The mean value of external financing variable is 52\%, whereas, the mean value of the debt to equity ratio is about $28 \%$. Yet, the standard 
Table 1 Variable definitions

\begin{tabular}{|c|c|c|c|}
\hline \multirow[t]{2}{*}{ Variable } & \multicolumn{2}{|c|}{ Expected Signs } & \multirow[t]{2}{*}{ Definition } \\
\hline & $\begin{array}{l}\text { Constrained } \\
\text { firms }\end{array}$ & $\begin{array}{l}\text { Unconstrained } \\
\text { firms }\end{array}$ & \\
\hline \multicolumn{4}{|l|}{ Dependent Variable } \\
\hline External_Financing & & & $\begin{array}{l}\text { External financing is the ratio of change in long-term } \\
\text { debt plus change in shareholders' equity to total assets. }\end{array}$ \\
\hline \multicolumn{4}{|l|}{ Independent Variables } \\
\hline Cash_Flow & -ve & -ve & $\begin{array}{l}\text { The net profit before tax plus depreciation for the year } \\
\text { divided by total assets. }\end{array}$ \\
\hline \multicolumn{4}{|l|}{ Control Variables } \\
\hline Growth & -ve/+ve & +ve & $\begin{array}{l}\text { Annual percentage change in total sales normalized by } \\
\text { consumer price index. }\end{array}$ \\
\hline Size & -ve/+ve & $+v e$ & Natural logarithm of book value of sales. \\
\hline Cash & + ve & -ve/+ve & Sum of cash and liquid securities divided by total assets \\
\hline Inventory & -ve/+ve & -ve & The ratio of inventories to total assets. \\
\hline $\begin{array}{l}\text { PPE (Plant, Property, } \\
\text { and Equipment) }\end{array}$ & -ve/+ve & -ve & The fixed assets divided by total assets. \\
\hline Debt/Equity & -ve & -ve/+ve & Total liabilities divided by total equity. \\
\hline
\end{tabular}

deviation indicates that the debt to equity ratio is more volatile as compared to external financing variable. The average cash flows are about $8 \%$. Firms hold about $7 \%$ of total assets on average in terms of cash and other marketable securities. The mean value of inventory is about $15 \%$ with the standard deviation of about $30 \%$. The mean value of tangible assets indicates that on average, firms hold $85 \%$ of their total assets in terms of fixed assets.

\section{Estimation technique}

To examine the relationship between external financing and cash flow under financial restrictions, researches have used different methods including ordinary least square, fixed effects, generalized method of moments, and instrumental variable approach. For example, Almeida \& Campello (2010) and Gracia \& Mira (2014) use ordinary least squares and generalized method of moments to measure the relation between external financing and cash flow. Frank \& Goyal (2003) use panel regression approach to examine the external financing decisions. However, Almeida et al., (2004) use generalized

Table 2 Descriptive statistics

\begin{tabular}{llllll}
\hline Variables & Mean & Std. Dev. & $Q_{1}$ & Median & $Q_{3}$ \\
\hline External_Financing & 0.5225 & 0.2679 & 0.4004 & 0.5515 & 0.6998 \\
Cash_Flow & 0.0869 & 0.3188 & 0.0145 & 0.0693 & 0.1475 \\
Growth & 0.2834 & 2.7863 & -0.0640 & 0.0864 & 0.2692 \\
Size & 7.2811 & 1.6792 & 6.1912 & 7.1486 & 8.3290 \\
Cash & 0.0748 & 0.1306 & 0.0055 & 0.0223 & 0.0820 \\
Inventory & 0.1506 & 0.3025 & 0.0000 & 0.1140 & 0.2480 \\
PPE & 0.8477 & 0.4565 & 0.5850 & 0.8208 & 1.0576 \\
Debt/Equity & 0.2756 & 42.8457 & 0.5752 & 1.3745 & 2.61729 \\
\hline
\end{tabular}

Note: Tables 2 and 3 presents the summary statistics. Table reports the mean, standard deviation, $Q_{1}$, median, and $Q_{3}$ values of the variables used in our regression model. Dependent variable is External_Financing while independent variables are Cash_Flows, Growth, Size, Cash, Inventory, PPE, (Plant, Property, and Equipment) and Debt/Equity 
Table 3 Financial constraint types

\begin{tabular}{lllc}
\hline $\begin{array}{l}\text { Financial Constraints } \\
\text { Criteria }\end{array}$ & $\begin{array}{l}\text { Constrained firms (CF) } \\
\text { (Firm-Year Obs.) }\end{array}$ & $\begin{array}{l}\text { Unconstrained firms (UCF) } \\
\text { (Firm-Year Obs.) }\end{array}$ & No of Obs. \\
\hline KZ Index & \\
Debt to Asset Ratio $i, t$ & 2890 & 2062 & 4809 \\
Interest Coverage Ratio & 2956 & 1996 & 4809 \\
\hline
\end{tabular}

Note: KZ Index stands for Kaplan and Zingales index

method of moments and ordinary least squares to study the empirical determinants of internal funds in the presence of financial constraints. We use fixed effects method to estimate Eq. (1). To take into account the problem of heteroskedasticity, we use robust standard errors.

The extended versions of external financing models presented in Eqs. (2) and (3) are dynamic in nature as they include the lagged dependent variable into the specification. The presence of the lagged dependent variable, EXTERNAL_FINANCING ${ }_{i}$, $\mathrm{t}-1$, in the set of explanatory variables may give rise to the problem of autocorrelation in the residuals. Further, the cash flow, the cash holding ratio, and the asset tangibility variables are likely to be endogenous because it is very likely that the causality may run in both directions - from these variables to external financing and vice versa. Thus, these variables may be correlated with the error term. Finally, our panel dataset has a short time dimension $(T=14)$ and a large firm dimension $(N=450)$. Because of these aspects, several econometric issues may arise from estimating the extended model of external financing. To over come these problems, we apply the two-step system GMM estimator.

Arellano \& Bond (1991), Arellano \& Bover (1995), and Blundell \& Bond (1998) develop the GMM estimator for a dynamic panel data. As in Rashid \& Waqar (2017), the GMM estimator is a suitable estimator for the case when (a) cross-sectional dimension is greater than time-series dimension, (b) the dependent variable is the function of its previous period realizations, (c) explanatory variables are endogenous in nature and likely to be correlated with the error term, (d) there is heteroskedasticity and autocorrelation in the individuals, and (e) researchers want to use different lags of level and first difference of the variables as the instruments. However, one should note that the reliability of the system GMM estimation results is highly conditional to the validity of the instruments. Hence, we apply the J test of Hansen (1982) for testing the validity of the instruments used in the estimation. We also apply the Arellano-Bond AR (2) test to observe the presence of the second-order serial correlation in the residuals.

\section{Empirical results}

As the primary aim of the paper is to examine the relationship between external financing and cash flow for financially constrained and unconstrained firms, we classify firm-year observations into financially constrained and unconstrained groups. For this purpose, we utilize three different measures, namely, the $\mathrm{KZ}$ index, the debt to asset ratio, and the interest coverage ratio. The classification of firm-year observations is presented in Tables 2 and 3. The debt to asset ratio and KZ index yield almost similar classification of firm-year observations, whereas, the interest rate coverage ratio identifies higher number of firm-year observations as financially constraints. 


\section{Estimating cash flow sensitivity of external financing}

We start empirical examination of how external financing decisions of firms relate to cash flow by estimating Eq. (1) for the full sample (combining both financially constrained and unconstrained firms). We do so to get preliminary insight regarding the relationship between external financing and cash flow for firms included in our analysis. The estimated coefficients are presented as follows; where the values in parentheses are standard errors. Following the previous studies on this topic, we estimate this model using the fixed effects method with robust standard errors.

$$
\begin{aligned}
& \text { EXTERNAL_FINANCING } \mathrm{i}_{\mathrm{i}, \mathrm{t}}=-0.0938 \times \text { CASH_FLOW }_{\mathrm{i}, \mathrm{t}}+0.0089 \times \text { GROWTH }_{\mathrm{i}, \mathrm{t}} \\
& (0.206) \\
& (0.003) \\
& +0.0153 \times(0.005) \text { SIZE }_{\mathrm{i}, \mathrm{t}} \\
& R^{2}=0.143 \\
& F=9.42 ; p-\text { value }=0.000
\end{aligned}
$$

The coefficient of cash flow indicates that there is a negative and statistically significant relationship between external financing and cash flows. The estimated value of the coefficient suggests that for each Pak rupee of internally generated cash flow shortfall, firms get about $9.4 \%$ in new external financing. The negative relationship is consistent with the prediction of the pecking order theory. This finding is also consistent with the findings of Fama \& French (2002), Leary \& Roberts (2005), and Almeida \& Campello (2010). The coefficient of growth suggests that the relationship between growth and external fund is positive and statistically significant. This result indicates that growing firms are more likely to raise funds from external sources. The positive relationship between firm growth and external funds is in agreement with the findings of Lemmon \& Zender (2010), Gracia \& Mira (2014), and Carpenter \& Petersen (2002). Finally, consistent with the trade-off theory, the estimated coefficient of firm size indicates that large-sized firms do more external financing. This finding is also confirmed by Fama \& French (2002), Titman \& Wessels (1988), and Hovakimian (2011). These results suggest that on average, the external financing decisions of firms operating in Pakistan are not only consistent with the capital structure theories but are also similar to the firms operation in developed countries like the UK and the USA.

\section{Empirical findings: baseline model}

In order to investigate the external financing - cash flow sensitivity under financial restrictions, we divide the firm-year observations into two groups: financially constrained and unconstrained firms. The fixed effects regression results with robust standard errors are presented in Table 4.

The estimation results reveal that cash flows are negatively related to the external financing decisions of both financially constrained and unconstrained firms. However, the negatively sensitivity of external financing to cash flow is considerably less for constrained firms as compared to their financially unconstrained counterparts. This finding holds for all three-classification criteria we used to classify the firm-year observations. It should also be noted that the estimated coefficient of cash flows appears statistically significant for financially unconstrained firms in case 
Table 4 Cash flow sensitivity of external financing: baseline model

\begin{tabular}{|c|c|c|c|c|c|}
\hline \multicolumn{6}{|l|}{ Independent Variables } \\
\hline $\begin{array}{l}\text { Dependent Variable: } \\
\text { External_Financing }\end{array}$ & Cash_Flow & Growth & Size & $F$-stat. (p-value) & No. of Obs. \\
\hline \multicolumn{6}{|l|}{ Panel A: KZ Index } \\
\hline Constrained firms (CF) & $\begin{array}{l}-0.0357 \\
(0.032)\end{array}$ & $\begin{array}{l}0.0083^{* * *} \\
(0.001)\end{array}$ & $\begin{array}{l}0.0229^{* * *} \\
(0.004)\end{array}$ & $\begin{array}{l}18.04 \\
(0.000)\end{array}$ & 2890 \\
\hline Unconstrained firms (UCF) & $\begin{array}{l}-0.1092^{* * *} \\
(0.002)\end{array}$ & $\begin{array}{l}0.0180^{* * *} \\
(0.007)\end{array}$ & $\begin{array}{l}0.0304^{* * *} \\
(0.011)\end{array}$ & $\begin{array}{l}25.45 \\
(0.000)\end{array}$ & 2062 \\
\hline \multicolumn{6}{|l|}{ Panel B: Debt to Asset Ratio } \\
\hline Constrained firms (CF) & $\begin{array}{l}-0.0181^{* * *} \\
(0.005)\end{array}$ & $\begin{array}{l}0.0020^{*} \\
(0.001)\end{array}$ & $\begin{array}{l}-0.0108^{* * *} \\
(0.001)\end{array}$ & $\begin{array}{l}493.14 \\
(0.000)\end{array}$ & 2956 \\
\hline Unconstrained firms (UCF) & $\begin{array}{l}-0.1088^{* * *} \\
(0.002)\end{array}$ & $\begin{array}{l}0.0218^{* *} \\
(0.009)\end{array}$ & $\begin{array}{l}0.0273^{* * *} \\
(0.008)\end{array}$ & $\begin{array}{l}862.63 \\
(0.000)\end{array}$ & 1996 \\
\hline \multicolumn{6}{|l|}{ Panel C: Interest Coverage Ratio } \\
\hline Constrained firms (CF) & $\begin{array}{l}-0.0231 \\
(0.028)\end{array}$ & $\begin{array}{l}0.0125^{* * *} \\
(0.006)\end{array}$ & $\begin{array}{l}0.0548^{* * *} \\
(0.010)\end{array}$ & $\begin{array}{l}10.22 \\
(0.000)\end{array}$ & 3920 \\
\hline Unconstrained firms (UCF) & $\begin{array}{l}-0.1819^{*} \\
(0.093)\end{array}$ & $\begin{array}{l}0.0378^{* * *} \\
(0.010)\end{array}$ & $\begin{array}{l}0.0252^{* *} \\
(0.011)\end{array}$ & $\begin{array}{l}38.52 \\
(0.000)\end{array}$ & 970 \\
\hline
\end{tabular}

Note: Table 4 displays the results of fixed effects model for the baseline regression model (Eq. (1)). The dependent variable is External_Financing, while the independent variables are Cash_Flows, Growth, and Size. Above Table reports three constrained criteria to divide the firms into constrained and unconstrained categories (the KZ Index, the debt to asset ratio, and the interest coverage ratio). We also report the estimated robust standard errors in parentheses. Last two columns show $F$-statistic along with its $\mathrm{p}$-value and number of observations. We do not report constant term to economize on space. ${ }^{* *}, * *$, and ${ }^{*}$ denote significant at the $1 \%, 5 \%$, and $10 \%$ level of significant, respectively

of all classification criteria, whereas, for financially constrained firms, it is only significant when the firms are classified based on the debt to assets ratio. These findings suggest that firms those do not confront any financial hindrance are more likely to reduce external financing in response to increased cash flows. These findings are consistent with the standard pecking order theory of capital structure.

The literature provides several explanations for such findings. First, financially unconstrained firms incur lower cost of external financing relative to financially constrained firms and can easily get the funds from the external capital market whenever they required external financing. Therefore, their external financing is more strongly, negatively related to internally generated funds. Second, since financially constrained firms are expected to face more asymmetric information problem and since the costs of information asymmetry is higher for such firms, they may also decrease their external financing in periods of positive cash flow shocks. Perhaps the firms do so to avoid the higher cost of information asymmetry and give a positive signal to outside investors (Myers (1984) and Myers \& Majluf (1984)). However, due to financial market frictions, financially constrained firms are relatively less able to decrease their external financing with increases in cash flows. Finally, as explained by Almeida \& Campello (2010), owing to the endogenous nature of investment for the case of financially constrained firms, the sensitivity of external financing to internally generated funds is less as compared to their financially unconstrained counterparts. Our finding on the negative relation between internal cash flow and external funds for financially constrained firms is consistent with the findings of Almeida \& Campello (2010), Gracia \& Mira (2014), and Portal et al., (2012). 


\section{Empirical findings: extended external financing model}

Having established the relationship between external financing and cash flow across financially constrained and unconstrained firms, we next estimate the extended external financing model depicted in Eq. (2), which takes into account firms' pre-existing stock of capital. Following the previous existing studies we estimate this model by applying the GMM estimator to mitigate the problem of possible endogeneity. Table 5 shows the results of the two-step system GMM considering external financing as dependent variable and cash flow, growth, size, cash, inventory, PPE, and debt/equity as independent variables. The estimated values of J-test suggest that the instruments used in the estimation are orthogonal to the residuals. The AR(2) test does not provide any significant evidence of the presence of the second order serial correlation in the residuals. These tests results ensure the validity of the instruments used in the estimations, confirming the reliability of the estimation results.

The results indicate that both groups of firms exhibit a negative sensitivity of external financing to cash flow. The results also suggest that the external financing is relatively more sensitive to cash flow shocks for financially unconstrained firms than financially constrained firms for all three financial constrained criteria. The less negative sensitivity of external financing to cash flow implies that financially constrained firms depend more on internally generated funds and are not independent to decide the investment. Hence, investment is endogenous to this category of firms. In contrast, financially unconstrained firms do not substantially depend on internally generated funds and thus, they are free to decide the investment due to less asymmetric information and agency cost problems. Therefore, investment appears exogenous to this type of firms. As a result, both types of firms show negative relationship, yet this relationship is much more intense in case of financially unconstrained firms.

\section{Measuring the impact of credit multiplier on firms' external financing decision}

In this section, we examine how credit multiplier affects the external financing decision for both groups of firms. W estimate Eq. (3) to test for the possibility that credit multiplier exerts differential effect on both groups of firms. While estimating the impact of credit multiplier on firms' external financing, we use external financing as the dependent variable and cash flow, growth, size, cash, inventory, PPE, debt/equity, tangibility (TANGIBILITY), and tangibility $\times$ cash flow (TANGIBILITY $\times$ CASH FLOW) as the independent variables. In order to ensure the validity of instruments used in the two-step system-GMM, we use the Arellano-Bond AR(2) test and Hansen J-test. ${ }^{6}$ The estimated results of cash flow, growth, size, cash, inventory, PPE, and debt/equity on external financing are similar to the earlier findings reported in Table 5. Specifically, the results presented in Table 6 provide evidence that cash flow has a significant, negative effect on external financing for both types of firms. Furthermore, the external financing and cash flow relationship is more intense for financially unconstrained firms as compared to financially constrained firms.

The results reported in the table provide evidence that the coefficient of tangibility is negative and statistically significant, indicating that firms having more tangible assets do less external financing regardless whether firms are financially constrained or unconstrained. The pecking order theory of capital structure also suggests that the relationship between tangibility and external financing is negative. As tangible assets are 


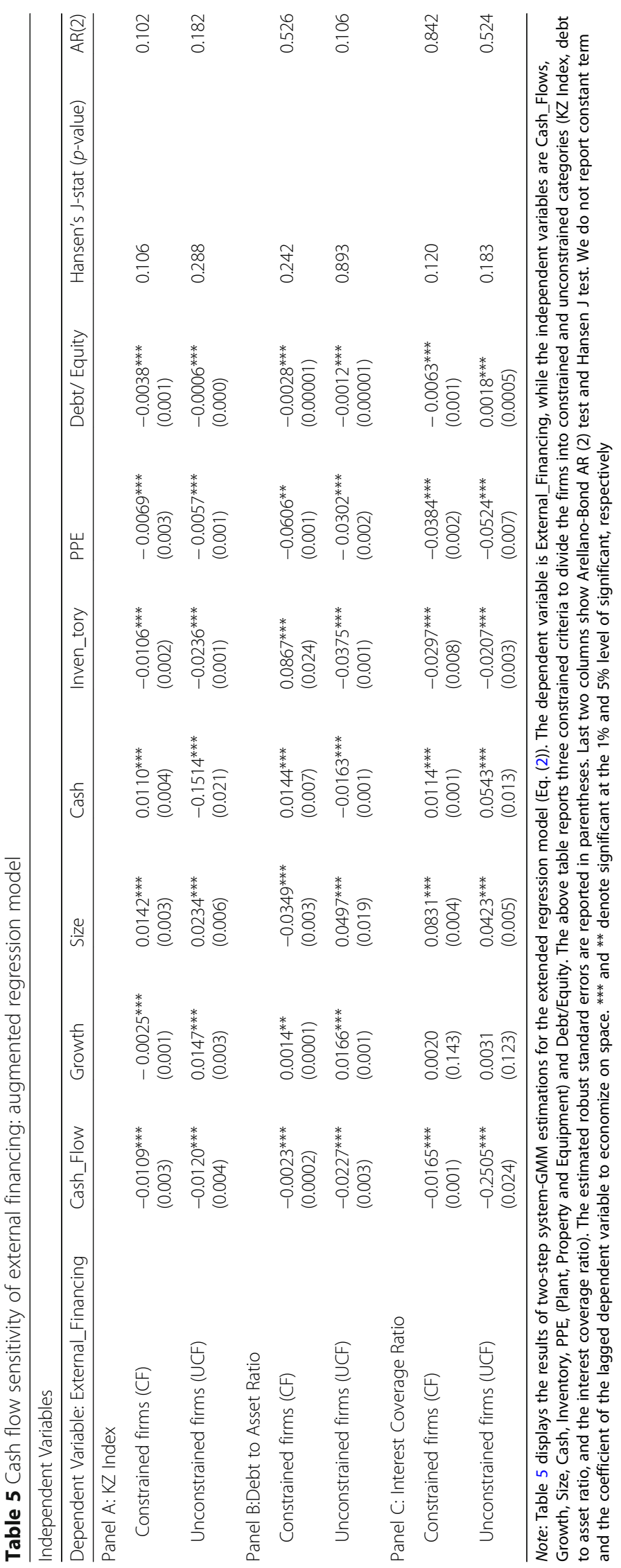




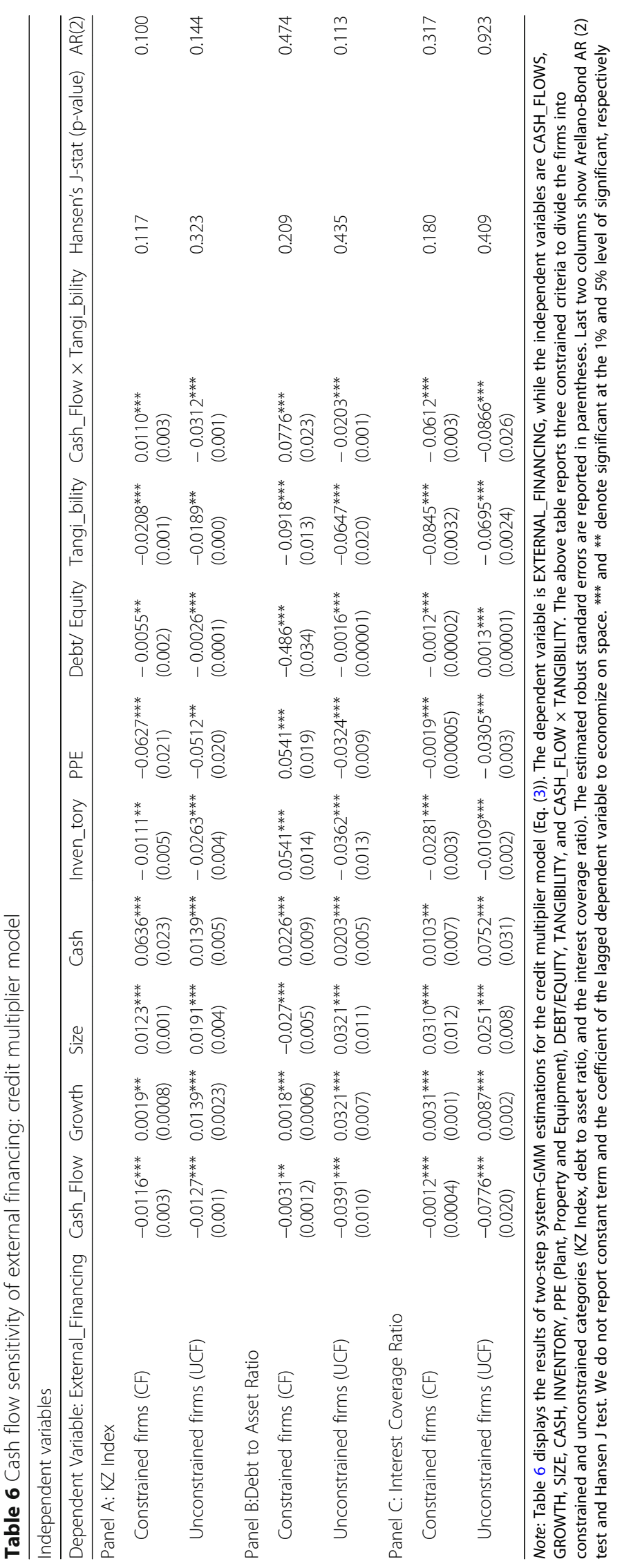


easier to value for outsiders than intangible asset, they lower the information asymmetries between managers and financers. Low information asymmetries decrease the cost of issuing new equity. We also find that the negative effect of tangibility on external financing is higher for financially constrained firms than financially unconstrained firms.

Turning to the estimates of the interaction between cash flows and tangibility, we find that the estimated coefficient of the interaction term is negative and significant for financially unconstrained firms in case of all three-classification criteria, whereas, for financially constrained firms, it is positive and significant for two out of three criteria. These results suggest that for financially unconstrained firms, the negative sensitively of external financing increases with asset tangibility. However, for financially constrained firms, the negative sensitivity of external financing to cash flow either decreases or turns positive as the tangibility of assets increases.

This negative estimated coefficient of the interaction term for financially constrained firms suggests the higher flexibility to adjust the external financing when they have more tangible assets. This is apparently obvious, particularly when financially constrained firms have surplus funds they prefer to invest more in tangible assets to mitigate information asymmetries and increase external financing capacities. Moreover, they prefer to have surplus fixed assets, which they can easily sell off in periods when they require funds. In contrast, financially unconstrained firms boasting more tangibility do not react in a different way to such cash flow shocks as they are supposedly unconstrained and determine external financing exogenously.

Our findings are also in accordance with the macroeconomic literature. It is assumed that those firms are likely to get more external financing which hold more tangible assets, which will lead to new tangible asset and in future new external financing and so on (Bernanke et al. (1996) and Kiyotaki \& Moore (1997)). Given this, it is assumed that firms those face difficulties in obtaining external funds try to accumulate more tangible assets and are more sensitive to credit multiplier effects.

\section{Conclusions}

In this paper, we examine the external financing - cash flow relationship under financial frictions for a large panel of Pakistani non-financial firms to understand why more profitable firms need less external funds. We take the ratio of long-term debt plus shareholders' equity to total assets as a proxy for external financing. We use three different classification methods to divide firm-year observations into financially constrained and unconstrained. We find a significant negative relationship between cash flow and external financing. We also find that the negative sensitivity of external financing to cash flow is higher for financially unconstrained firms as compared to their financially constrained counterparts.

Our results suggest that when constrained firms face shocks, they tend to reduce less amount of external financing as compared to financially unconstrained firms. Presumable, under financial frictions, information asymmetries are not the core of the decision. As an alternative, what is important and accountable for this decision is the endogeneity of investment for financially constrained firms because they are facing financial frictions while seeking external funds. These results also suggest that the pecking order has a significant impact on the capital structure decisions of firms. 
Further, we investigate the impact of asset tangibility on the relationship between cash flow and external financing for both types of firms. We find that for financially constrained firms, the tangibility of assets plays an important role in adjusting the capital structure of firms. Finally, we show that financially constrained firms have higher flexibility to seek external funds when they have higher amount of tangible assets. Our findings help firm managers and investors to understand how external financing strategies of corporate firms are affected by cash flow shocks, particularly in the presence of financial market frictions. The findings on the relationship between cash flow and external financing are useful in understating the role of asymmetric information and the nature of investment for firms those face as well as those do not face difficulties in obtaining external finance. Our findings also help understand the role of the tangibility of assets in establishing the relationship between internally generated funds and external financing. Finally, our empirical analysis is also of significance to policymakers as it suggests that the policies to lessen financial market frictions would be helpful to corporate firms to access external capital markets, increase investment, and in turn, enhance economic growth of the economy.

\section{Endnotes}

${ }^{1}$ We would like to thank independent referees and the Editor for their constructive suggestions and comments. The usual disclaimer applies.

${ }^{2}$ See, for example, Allayannis \& Mozumdar (2004) and Brown, Fazzari, \& Petersen (2009) for more on these lines.

${ }^{3}$ One should note that we just start our empirical analysis by estimating this non-dynamic model of external financing to produce a set of results, which is comparable with the findings of existing studies, as several scholars have estimated this model to discuss the underlying issue.

${ }^{4}$ As pointed out by the referee, one of potential limitations of our external finance measure is that it does not capture the flow of new external financing that is going into the firm.

${ }^{5}$ Almeida, Campello, \& Weisbach (2004) and Hadlock \& Pierce (2010) have proposed the use of firm age and the SA index for identifying blinding financial constraints.

${ }^{6}$ We use lag 2 to lag 6 of the variables as instruments in our estimation.

\section{Acknowledgements}

We are thankful to Zainab Jehan and Maria Karim for their useful comments on the first draft of the paper. We are grateful to the anonymous referees of the journal for their extremely useful suggestions to improve the quality of the article. The usual disclaimer applies.

Funding

We hereby confirm that we do not avail any funding for this research paper/study.

Availability of data and materials

The datasets used and/or analysed during the current study are available from the corresponding author on reasonable request at ch.arahmad@yahoo.com.

Authors' contributions

My co-author collected and done the initial screening of the data used in the empirical analysis. We together conducted the empirical analysis of the paper. She collected and reviewed the relevant literature review. I interpreted the results and finally we together read and finalized the paper. Both authors read and approved the final manuscript. 


\section{Publisher's Note}

Springer Nature remains neutral with regard to jurisdictional claims in published maps and institutional affiliations.

\section{Received: 23 February 2017 Accepted: 2 July 2018}

Published online: 13 July 2018

\section{References}

Allayannis G, Mozumdar A (2004) The impact of negative cash flow and influential observations on investment - cash flow sensitivity estimates. J Bank Financ 28(5):901-930

Almeida H, Campello M (2007) Financial constraints, asset tangibility, and corporate investment. Rev Financ Stud 20(5): 1429-1460

Almeida H, Campello M (2010) Financing frictions and the substitution between internal and external funds. J Financ Quant Anal 45(3):589-622

Almeida H, Campello M, Weisbach MS (2004) The cash flow sensitivity of cash. J Financ 59(4):1777-1804

Arellano M, Bond S (1991) Some tests of specification for panel data: Monte Carlo evidence and an application to employment equations. Rev Econ Stud 58(2):277-297

Arellano M, Bover O (1995) Another look at the instrumental variable estimation of error-components models. J Econ 68(1):29-51

Arslan-Ayaydin Ö, Florackis C, Ozkan A (2014) Financial flexibility, corporate investment and performance: evidence from financial crises. Rev Quant Finan Acc 42(2):211-250

Arugaslan O, Miller L (2006) On the conditioning of the financial Market's reaction to seasoned equity offerings. Lahore J Econ 11(2):141-154

Baños-Caballero S, García-Teruel PJ, Martínez-Solano P (2014) Working capital management, corporate performance, and financial constraints. J Bus Res 67(3):332-338

Bernanke B, Gertler M, Gilchrist S (1996) The financial accelerator and the flight to quality. Rev Econ Stat 78(1):1-15

Blundell R, Bond S (1998) Initial conditions and moment restrictions in dynamic panel data models. J Econ 87(1): 115-143

Borisova G, Brown JR (2013) R\&D sensitivity to asset sale proceeds: new evidence on financing constraints and intangible investment. J Bank Financ 37(1):159-173

Brav $O$ (2009) Access to capital, capital structure, and the funding of the firm. J Financ 64(1):263-308

Brown J, Fazzari S, Petersen B (2009) Financing innovation and growth: cash flow, external equity, and the 1990s R\&D boom. J Financ 64(1):151-185

Brown JR, Petersen BC (2009) Why has the investment-cash flow sensitivity declined so sharply? Rising R\&D and equity market developments. J Bank Financ 33(5):971-984

Brown JR, Petersen BC (2015) Which investments do firms protect? Liquidity management and real adjustments when access to finance falls sharply. J Financ Intermed 24(4):441-465

Caglayan M, Rashid A (2014) The response of firms' leverage to uncertainty: Evidence from UK public versus non-public firms. Econ Inq 52(1):341-361

Campello M, Hackbarth D (2012) The firm-level credit multiplier. J Financ Intermed 21(3):446-472

Carpenter RE, Petersen BC (2002) Is the growth of small firms constrained by internal finance? Rev Econ Stat 84(2):298-309

Chen HJ, Chen SJ (2012) Investment-cash flow sensitivity cannot be a good measure of financial constraints: evidence from the time series. J Financ Econ 103(2):393-410

Cleary S (1999) The relationship between firm investment and financial status. J Financ 54(2):673-692

Fama EF, French KR (2002) Testing trade-off and pecking order predictions about dividends and debt. Rev Financ Stud 15(1):1-33

Faulkender M, Petersen MA (2006) Does the source of capital affect capital structure? Rev Financ Stud 19(1):45-79

Fazzari, Hubbard RG, Petersen BC (1988) Financing constraints and corporate investment. Brook Pap Econ Act 1:141195

Fazzari SM, Petersen BC (1993) Working capital and fixed investment: new evidence on financing constraints. RAND J Econ 24(3):328-342

Frank MZ, Goyal VK (2003) Testing the pecking order theory of capital structure. J Financ Econ 67(2):217-248

Gracia LJ, Mira SF (2014) Sensitivity of external resources to cash flow under financial constraints. Int Bus Rev 23(5):920-930

Graham JR (2000) How big are the tax benefits of debt? J Financ 55(5):1901-1941

Graham JR, Harvey CR (2001) The theory and practice of corporate finance: evidence from the field. J Financ Econ 60(2):187-243

Hadlock CJ, Pierce JR (2010) New evidence on measuring financial constraints: moving beyond the KZ index. Rev Financ Stud 23(5):1909-1940

Hansen LP (1982) Large sample properties of generalized method of moments estimators. Econometrica 50(4): 1029-1054

Hovakimian G (2011) Financial constraints and investment efficiency: internal capital allocation across the business cycle. J Financ Intermed 20(2):264-283

Hubbard RG (1998) Capital-market imperfections and investment. J Econ Lit 36:193-225

Kadapakkam P-R, Kumar P, Riddick LA (1998) The impact of cash flows and firm size on investment: the international evidence. J Bank Financ 22(3):293-320

Kaplan SN, Zingales L (1997) Do Investment-cash flow sensitivities provide useful measures of financing constraints? Q J Econ 112(1):169-215

Kim TN (2014) The impact of cash holdings and external financing on investment-cash flow sensitivity. Rev Account Finance 13(3):251-273

Kiyotaki N, Moore J (1997) Credit cycles. J Polit Econ 105(2):211-248 
Leary MT, Roberts MR (2005) Do firms rebalance their capital structures? J Financ 60(6):2575-2619

Lemmon ML, Zender JF (2010) Debt capacity and tests of capital structure theories. J Financ Quant Anal 45(05): $1161-1187$

Myers SC (1977) Determinants of corporate borrowing. J Financ Econ 5(2):147-175

Myers SC (1984) The Capital Structure Puzzle. J Financ 39(3):574-592

Myers SC, Majluf NS (1984) Corporate financing and investment decisions when firms have information that investors do not have. J Financ Econ 13(2):187-221

Portal MT, Zani J, Silva CESD (2012) Financial frictions and substitution between internal and external funds in publicly traded Brazilian companies. Rev Contabilidade Fin 23(58):19-32

Rajan RG, Zingales L (1995) What do we know about capital structure? Some evidence from international data. J Financ 50(5):1421-1460

Rashid A, Waqar SM (2017) Exchange rate fluctuations, firm size, and export behavior: an empirical investigation. Small Bus Econ 49(3):609-625

Schoubben F, Van Hulle C (2011) Stock listing and financial flexibility. J Bus Res 64(5):483-489

Shyam-Sunder L, Myers SC (1999) Testing static tradeoff against pecking order models of capital structure. J Financ Econ 51(2):219-244

Strebulaev IA (2007) Do tests of capital structure theory mean what they say? J Financ 62(4):1747-1787

Titman S, Wessels R (1988) The determinants of capital structure choice. J Financ 43(1):1-19

Whited TM (1992) Debt, liquidity constraints, and corporate investment: evidence from panel data. J Financ 47(4):1425-1460

Whited TM, Wu G (2006) Financial constraints risk. Rev Financ Stud 19(2):531-559

Submit your manuscript to a SpringerOpen ${ }^{\circ}$ journal and benefit from:

- Convenient online submission

- Rigorous peer review

- Open access: articles freely available online

- High visibility within the field

Retaining the copyright to your article

Submit your next manuscript at $>$ springeropen.com 